\title{
Kentsel Koruma Politikaları Kapsamında Isparta Tarihi Kent Merkezi Kimliğinin Sürdürülebilirliği
}

\author{
Eda Çelik ${ }^{*}$, Ali Türk2 \\ ${ }^{1 *}$ Süleyman Demirel Üniversitesi, Mimarlık Fakültesi, Şehir ve Bölge Planlama Bölümü, Isparta, Türkiye, (ORCID: 0000-0002-7121-9945), \\ edacelik1691@gmail.com \\ ${ }^{2}$ Süleyman Demirel Üniversitesi, Mimarlık Fakültesi, Şehir ve Bölge Planlama Bölümü, Isparta, Türkiye (ORCID: 0000-0002-9934-0915), aliturk@sdu.edu.tr
}

(İlk Geliş Tarihi 30 Mart 2021 ve Kabul Tarihi 20 Eylül 2021)

(DOI: 10.31590 /ejosat.906611)

ATIF/REFERENCE: Çelik, E., Türk, A. (2021). Kentsel Koruma Politikaları Kapsamında Isparta Tarihi Kent Merkezi Kimliğinin Sürdürülebilirliği. Avrupa Bilim ve Teknoloji Dergisi, (27), 676-685.

$\ddot{O} \mathbf{z}$

Hızlı kentleşme, kentlerin tarih boyunca edinmiş oldukları fiziksel, mekânsal ve kültürel birikimlerin; başka bir ifadeyle kimliklerinin zarar görmesine neden olmaktadır. Yaşanan bu hızlı ve çarpık kentleşme sonucu olarak kentler kültürel mirasın göz ardı edildiği ve kent kimliğinin olumsuz olarak etkilendiği bir sürece girmiştir. Kentler bu süreçte özgünlüklerini kaybederek tek tipleşen kent formları haline gelmiştir. Kentsel kimliğin sürdürülebilirliği yasal düzenlemelerle güvence altına alınmadığında gelecek nesillere aktarılamamaktadır. Bu sebeple kentlerin birbirinden ayırt edilmesine imkân veren kentsel kimliğin sürdürülebilirliğinin sağlanmasında koruma politikalarının rolü önem arz etmektedir. Bu çalışmada kentsel kimliğin sürdürülebilirliğinde kentsel koruma politikalarının rolünü araştırmak amaçlanmıştır. Bu kapsamda Isparta Kent'inin tarihi kent merkezinde yer alan konut dışı sivil mimari yapılarının ve ticari bölgenin bulunduğu tarihi sit alanı ile kentsel sit alanı örneklem olarak belirlenmiştir. Söz konusu alandaki mevcut durum; kat adedi, tarihsel dönemleme, tarihi değerlilik analizi gibi nicel yöntemlerle incelenerek tarihi kent merkezinin kentin kimliğine olan etkisi ve bu kimliğin sürdürülülebilirliğinde koruma politikalarının rolü ortaya konulmuştur.

Anahtar Kelimeler: Kentsel Kimlik, Sürdürülebilirlik, Kentsel Koruma, Isparta Tarihi Kent Merkezi.

\section{Sustainability of Isparta Historical City Center Identity within the Scope of Urban Protection Policies}

\begin{abstract}
Rapid urbanization causes the destruction of their physical, spatial and cultural accumulation of cities throughout history, in other words their identity. As a result of this rapid and distorted urbanization, cities have entered a period in which cultural heritage is ignored and urban identity is negatively affected. Cities have lost their originality in this process and become uniform urban forms. of urban identity cannot be transferred to future generations when it is not guaranteed by legal regulations. For this reason, the role of conservation policies is important in ensuring the sustainability of urban identity that enables the differentiation of cities. aim of this study is to investigate the role of urban conservation policies in sustainability of urban identity. In this context, the historical site area of Isparta City is located in the historical city center and the commercial area of the non-residential civil architecture and urban site area is determined as an example. The effect of the city's identity of the historical city center examined quantitative methods such as number of floors, historical period, historical value analysis and the role of protection policies in the sustainability of this identity has been revealed.
\end{abstract}

Keywords: Urban Identity, Sustainability, Urban Conservation, Isparta Old Town.

\footnotetext{
* Sorumlu Yazar: edacelik1691@gmail.com
} 


\section{Giriş}

Sanayi devrimi ile beraber kent ve ilişki içerisinde olduğu yakın çevresinde iş olanakları artmış ve bu durum kentlere göçü artırmıştır. Artan göç nihayetinde kentlerin nüfusunda yoğun bir artı̧ meydana gelmiş ve kentsel alandaki ekonomik, çevresel, kültürel ve toplumsal değerlerin tüketimiyle karşı karşıya kalınmıştır. Rekabetin de büyük etkisi ile birlikte kentler yaşanan hızlı ve çarpık kentleşme sonucunda kültürel mirasın göz ardı edildiği ve kent kimliğinin olumsuz olarak etkilendiği bir sürece girmiştir. Kentler bu süreçte özgünlüklerini kaybederek tek tipleşen kent formları haline gelmiştir.

Kentin sahip olduğu kimlik günümüz şartlarıyla biçim alarak gelecek nesillere ulaştırılmalıdır. Bu durum da fiziksel ve sosyal yapıdaki süreklilik ile gerçekleştirilebilir. Bu kapsamda koruma planlarında kent kimliğini önemseyen unsurlara yer verme kent kimliğinin korunup devam ettirilmesinde önemli bir rol oynayacaktır. Kent kimliğinin muhafaza edilmesi, tarihi değere sahip olan kentsel dokunun yeniden canlandırılması, fiziki, sosyal ve ekonomik mekânların bir arada düşünülmesi ve planlanması şartı çağdaş koruma anlayışının çerçevesini oluşturmaktadır.

Kentlerin kendine has özellikleri günümüzde onları birbirinden ayırt edebilmek için önemini koruyan unsurlardır. Küreselleşmenin de etkisiyle mekânsal ve kültürel olarak kentler birbirine benzemekte, bu durum da sahip oldukları ayırt edici özellikleri önemli kılmaktadır (Paul, 2004, s. 572). Tüm dünyanın etkilendiği bu değişim ve dönüşüm süreci ile birlikte kent kimliğine dair bize fikir veren tarihi kent merkezleri kendi haline bırakılmış ve bu durum da dokularında ve karakterlerinde geri dönüşü olmayan kayıplara yol açmıştır (Clammer, 2003). Zaman içerisinde değişime uğrayan kent formları içerisinde barındırdıkları farklı değer ve sistemlerin çatışmaları sonucu meydana gelir ve bu farklılar kentin kimliğini oluşturur (Kong, 2000: 354 Kroft, 1996: 247-263).

Kentlerin tasvir edilip diğer kentlerden ayırt edilmesine yardımcı olan özelliklerin bütünü kent kimliğini oluşturmaktadır. Kentin kimliğinin belirleyicisi ise tüm bu niteliklerin etkileşiminden meydana gelen bütünün karakteristiğidir (Gündüz ve Taner, 2001). Tekeli'nin de ifade ettiği üzere, bir mekânda yaşayan kişiler o mekâna değer yükleyip, oraya bağlandıklarında, yükledikleri bu değerler uğruna bazı fedakârlık yapmaya başladıklarında, o mekân bir kimliğe sahip olacaktır. Bir başka ifade ile kentin kimliği, üzerinde yaşayan toplumlar tarafından inşa edilir (Tekeli, 1991).

Erkmen (1990), her insan ve yapının bir kimliğe sahip olduğu gibi kentlerin de bir kimliğinin, kentleri o kent yapan niteliklerinin var olduğunu ve olması gerektiğini ifade etmiştir. Kentlerin birbirinden ayırt edilmesine yarayan en önemli özellik, zamanla kazandıkları kendilerine has karakterleridir. $\mathrm{Bu}$ karakter, yer aldığı ve doğduğu coğrafyadan, içerisinde yaşattı̆̆ 1 insanlara kadar uzanan bir sistemde sürekli değişip gelişim göstererek kentin etiketini oluşturmaktadır (Şahin, 2010 s.153).

Bir kentin kimliğinin oluşumunda o kentin mimarisi büyük öneme sahiptir. Dönemlerin mimari anlayışları, yapı malzemeleri, toplumun sosyo-kültürel, fiziksel ve ekonomik yapısı, kullanıcı istekleri ve tasarlayanın bakış açısı kent e-ISSN: $2148-2683$ kimliğini etkilemektedir. Mimari üsluba bağlı olarak kentlerin kimliğinin oluşumunda tasarımcının rolü oldukça büyüktür (İlgar, 2008 s.10). Lynch'e göre (2017) "Bir kenti başkalaştırmaya yardımcı olan nitelikler ve kente özgü olduğu tartışma götürmeyen öğeler” olarak tanımlanan kent kimliği, kentin yer aldığı bölgeye ve üzerinde yaşayanların kültürel ve sosyal özelliklerine göre farklı beliryeciler ile şekillenmektedir. $\mathrm{Bu}$ belirleyiciler sadece kentin yer aldığı bölgeyle sınırlı kalmamaktadır. Kentin sahip olduğu doğal çevre özellikleri ve bu özellikler doğrultusunda oluşan yapay çevre özellikleri, tarihi, kültürel ve ekonomik yapının oluşturduğu sosyo kültürel özellikler de bu belirleyiciler arasındadır. Kentin kimliğini oluşturan bu belirleyicilerin hepsi birbiriyle etkileşim durumundadır (Jacops, 2011). Tüm bu etkileşim içindeki bileşenler ve onların meydana getirdiği kimlik geçmişten günümüze kentin karakterine dair kullanıcılara bilgiler vermektedir. $\mathrm{Bu}$ sebeple kentsel kimliğin sürdürülebilirliği geçmiş ve gelecek arasında kente dair bilgiler sunmasından ötürü önem arz etmektedir.

Gelişmiş Batı Ülkeleri'nin birçoğunda ülke yönetiminin, kent planlama sistemine yaklaşımında üzerinde durduğu anahtar kavram olan sürdürülebilirlik; çevresel, toplumsal ve ekonomik ihtiyaçların, gelecekteki kuşakların yaşam şartlarını zarara uğratmadan karşılanmasını amaçlayan bir dünya görüşü olarak kabul görmüştür. Sürdürülebilirlik gelişmiş bir çevrenin amaçlarına ulaşmaya yönlenen, küresel politik alanda şekillenen bir olgu olup, yerine getirilmesi gereken bir şarttır (Oktay, 2007 s.37). Dolayısıyla kentin kimliğinin sürdürülebilir olması aynı düğnya görüşünde kabul görmektedir.

Çalışmanın konusu, mekânsal ve işlevsel açıdan kent kurgusu bağlamında bütünlük-süreklilik gösteren 2 (iki) farklı karakteristik ve statü gösteren Isparta tarihi kent merkezi olarak belirlenmiştir. Birincisi, Atatürk Parkı, Bedesten Çarşısı, Valilik, Bey Hamamı ve Ulu Cami'nin de içinde yer kamusal ve anıtsal yapılardan oluşan Tarihi Sit Alanıdır. İkincisi, Üzüm Pazarı olarak tarif edilen Atatürk Bulvarı ile Mimar Sinan Caddesi kesişiminde yer alan ticari yapıların oluşturduğu "Kentsel Sit Alanıdır. Üçüncüsü ise Üzüm pazarı olarak tanımlanan bölgede yer alan "Korunacak Sokak" statüsündeki koruma alanıdır. Bu farklı statüde olmakla birlikte tarihsel, mekânsal ve işlevsel açıdan bütünlük-süreklilik gösteren koruma alanları, Antalya Kültür ve Tabiat Varlıkları Koruma Bölge Kurulu'nun 21.01.2013 tarih ve 1350 sayılı kararı ile Isparta Sit Alanı olarak ilan edilmiştir (Şekil 1).

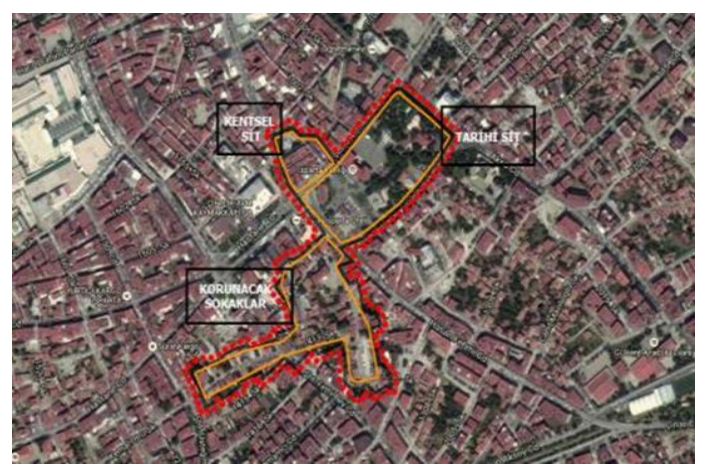

\section{Şekil 1. Çalışma Konusu Alan; Isparta Tarihi Kent Merkezi}

$\mathrm{Bu}$ çerçevede, çalışmanın amacı, farklı statüdeki koruma alanlarından oluşan Isparta tarihi kent merkezinin kendine özgü 
kimlik değerlerinin, mevcut durumunun incelenerek, yapısal ve fiziksel niteliklere ilişkin haritalar üretilmesine dayanan morfolojik analizler yardımıyla kentin kimliğine olan etkisinin sorgulanarak, kent kimliğinin sürdürülülebilir kılınmasına yönelik öneriler sunulmasıdır.

\section{Materyal ve Metot}

\subsection{Konu-Kapsam ve Yöntem}

Çalışma alanının temel gerekçe; farklı statüdeki koruma alanları (tarihi sit, kentsel sit, korunacak sokak gibi) bulunması bağlamında mekânsal ve işlevsel açıdan kent kimliğine katkı koyan simgesel kamusal ve anıtsal yapılardan oluşmasıdır.

Çalışmanın kapsamı; Isparta tarihi kent merkezinde anıtsal ve kamusal mimari özelliğe sahip yapıların yer aldığı "tarihi sit alanı" ile geleneksel çarşı niteliğinde olan ticari aktivitelerin hala devam ettirildiği "kentsel sit alanı" ile "korunacak sokak" dokuları oluşturmaktadır. Bu çerçevede, çalışma alanı ve yakın çevresi kentsel kimlik bağlamında bütün olarak değerlendirilmiş, bu bütünlüğü bozan yapılaşmaların hangi tarihten itibaren, nasıl bozulmaya uğradığ analizlerle saptanmaya çalışılmıştır. $\mathrm{Bu}$ doğrultuda, çalışma alanına ilişkin "kent kimliğii" ve "koruma" birlikteliğini esas alan akademik-bilimsel yayınlar incelenmiş $1 / 1.000$ ölçekle hazırlanan analiz haritalarında yapıların mimari ve tarihsel değerlilik özellikleri ile mevcut durum analizi yapılmıştır.

Yöntem kapsamında öncelikle çalışma alanı ve yakın çevresine ilişkin tespit ve gözlem-fotoğraflama içerikli saha araştırmaları yapılmıştır. Sonrasında, elde edilen veriler Netcad, Photoshop ve Office programlariyla bilgisayar ortamında haritalar üzerine aktarılarak değerlendirilmiştir. $\mathrm{Bu}$ değerlendirmeler, onaylı hâlihazır haritalar üzerinde mülkiyet durumu, kat yüksekliği, yapım tekniği ve malzemesi, yapı kullanım biçimleri, yapısal durum, sit alanı ve tescilli yapılar, korunmuşluk durumu, tarihsel dönemleme ve tarihsel değerlilik analizlerinden oluşmaktadır..

Kaynak araştırması kapsamında ise üniversite kütüphanelerinden ilgili tezlerin sorgulanması, kitap ve makalelerin araştırılmasından oluşan literatür taraması yapılmıştır. Devamla, alanın hukuksal niteliği bağlamında ilgili kanun, yönetmelik ve koruma kararları irdelenmiştir. $\mathrm{Bu}$ noktada, Antalya Kültür ve Tabiat Varlılarını Koruma Bölge Kurulu Kararları, Isparta Belediyesi'nde tarihi kent merkezine yönelik kentsel koruma ve yenileme çalışmaları incelenmiştir.

\section{1. Çalışma Alanının Karakteristiği}

\subsubsection{Planlama Çalışmaları ve Koruma Kararları}

Kentin planlama süreci irdelenirse, mekânsal-işlevsel kurallara bağlanma gerekliliğinin, 1848 senesinde ortaya çıktığ söylenebilir. Bu çerçevede, 1848 tarihli Ebniye Nizamnamesi kapsamında öngörülen mekânsal düzenleme ve kuralların başta İstanbul olmak üzere Anadolu kentlerinde uygulanmaya başladığı görülmektedir. Ancak, imar planı çalışmalarının esas itibarıyla Cumhuriyet döneminde gündeme alındığ görülmektedir. Nitekim kentin ilk imar planı Prof. Öelsner tarafından 1944 yılında hazırlanmıştır. 1938-1944 dönemini kapsayan altı yıllık süreçte hazırlanan imar planı, kentin
Cumhuriyet dönemindeki mekânsal gelişimini etkileyenyönlendiren önemli bir unsur olmuştur.

Plan kapsamında ticaretin gerçekleştirildiği merkez bölgesi ile merkezi çevreleyen konut bölgesinden oluşan tarihi çevrenin korunduğu, kentsel gelişmenin ise kuzeyde İstasyon bölgesine yönlendirildiği görülmektedir. (Öelsner, 1942, s.1780). Dolayısıyla, Isparta tarihi kent merkezinin korunması yönelik ilk çabanın, 1944 tarihli ilk imar planı ile başladığını söylemek mümkündür (Şekil 2).

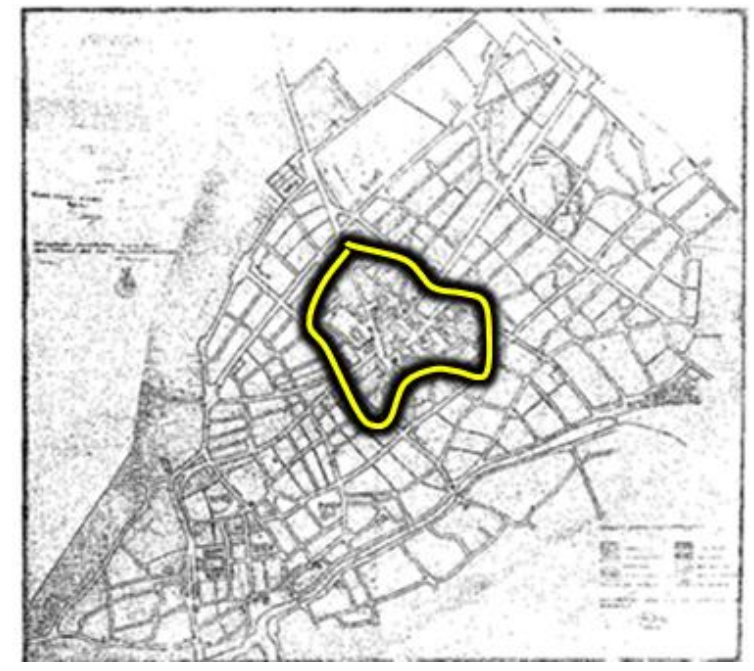

Şekil 2. Isparta Tarihi Kent Merkezi, İlk İmar Planı (1944)

Tarihi kent merkezinin korunmasina yönelik ilk yasal düzenleme ise 1977 yılında Gayrimenkul Eski Eserler Anıtlar Yüksek Kurulu Kararı ile tarihi kent merkezi ve yakın çevresinin 1. ve 2. Derece Sit Alanı olarak ilan edilmesi olmuştur. Ancak, 1984 yılında koruma statüsünün kaldırılması, tarih kent merkezinin mekânsal ve işlevsel kimliğinin korunması konusunda önemli sorunlar ortaya çıkarmıştır. Bu süreçte, tarihi kent merkezi ve yakın çevresinin çok katlı yapılaşma talepleri nedeniyle özgün kimliğinin bozulma riski ile karşı karşıya kaldığı görüşmektedir. Nitekim 1990’lardaki çevre düzenleme çalışmalarında Bedesten ve Valilik Binası arasında kalan alan yıkılarak tanımsız bir hale getirilirken, Kaymak Kapı Meydanı'nın batısında yer alan küçük dükkân ve hanlar yıkılarak, Belediye İş Hanı inşa edilmesi ile geleneksel tarihsel dokular yitirilmiştir.

Bu süreç sonunda, Atatürk Parkı, Bedesten Çarşısı, Valilik, Bey Hamamı ve Ulu Cami'nin içinde bulunduğu alan Antalya Kültür ve Tabiat Varlıkları Koruma Kurulu'nun 25.09.1990 gün ve 901 sayılı kararı ile "Tarihi Sit Alanı", Atatürk Bulvarı ile Mimar Sinan Caddesi kesişiminde yer alan ticari yapıların oluşturduğu bölge ise Antalya Kültür ve Tabiat Varlıkları Koruma Kurulu'nun 28.07.1992 gün ve 1495 sayılı kararı ile "Kentsel Sit Alanı" olarak ilan edilmiştir. Devam eden süreçte, Üzüm Pazarı ticari yapıların oluşturduğu bölge ise Antalya Kültür ve Tabiat Varlıkları Koruma Kurulu'nun 21.01.2013 tarih ve 1350 sayılı ile "Korunacak Sokak" olarak belirlenmiştir.

Isparta tarihi kent merkezine ilişkin son koruma kararı ise "Tarihi Sit Alanı", "Kentsel Sit Alanı" ve "Korunacak Sokaklar" olarak ilan edilen koruma statü alanlarının, Antalya Kültür ve Tabiat Varlıkları Koruma Bölge Kurulu'nun 21.01.2013 tarih ve 1350 sayılı kararı ile birleştirilerek Isparta Sit Alanı olarak ilan edilmesidir. $\mathrm{Bu}$ koruma statü kararı, Isparta tarihi kent merkezinin mekânsal ve işlevsel bağlamda kimlik bütünlüğünün sağlanması bakımından önemlidir. 


\subsubsection{Mekânsal ve İşlevsel Kimlik Değerleri}

Çalışma alanı Valilik binası, Ulucami, Firdevsbey Bedesteni, Dalboyunoğlu Hamamı olmak üzere kamusal yapıların bulunduğu alan ile Mimar Sinan Camii ile Üzüm Pazarını kapsamakta olup kentin geçirmiş olduğu tarihsel süreçteki mekânsal ve işlevsel kimliğine dair izler barındırmaktadır.

Mekânsal ve işlevsel kimlik değerleri açısından bakılırsa, Osmanlı dönemi mimari üslubunu yansıtan camiler ile birlikte hamam, bedesten ve Valilik gibi kamusal hizmet binaları önemli "simgesel yapılar" olarak görülebilir.
Kent kimliğini tanımlayan simgesel yapılar ayrıntıda incelendiğinde, kentin dini odak yapıları işlevindeki Ulucami ile 1569 yllında inşa edilen Mimar Sinan Camisi, kentin idari merkezi niteliğindeki Valilik binası, kentin ekonomik etkinlik merkezi olarak ticaret faaliyetlerine konu olan Firdevsbey Bedesteni (1561) ve Üzüm Pazarı (1561) kentin sosyal hizmet yapıları arasında sayılan Bey Hamamı ve Dalboyunoğlu Hamamı (1693) olarak sıralanabilir (Şekil 3).

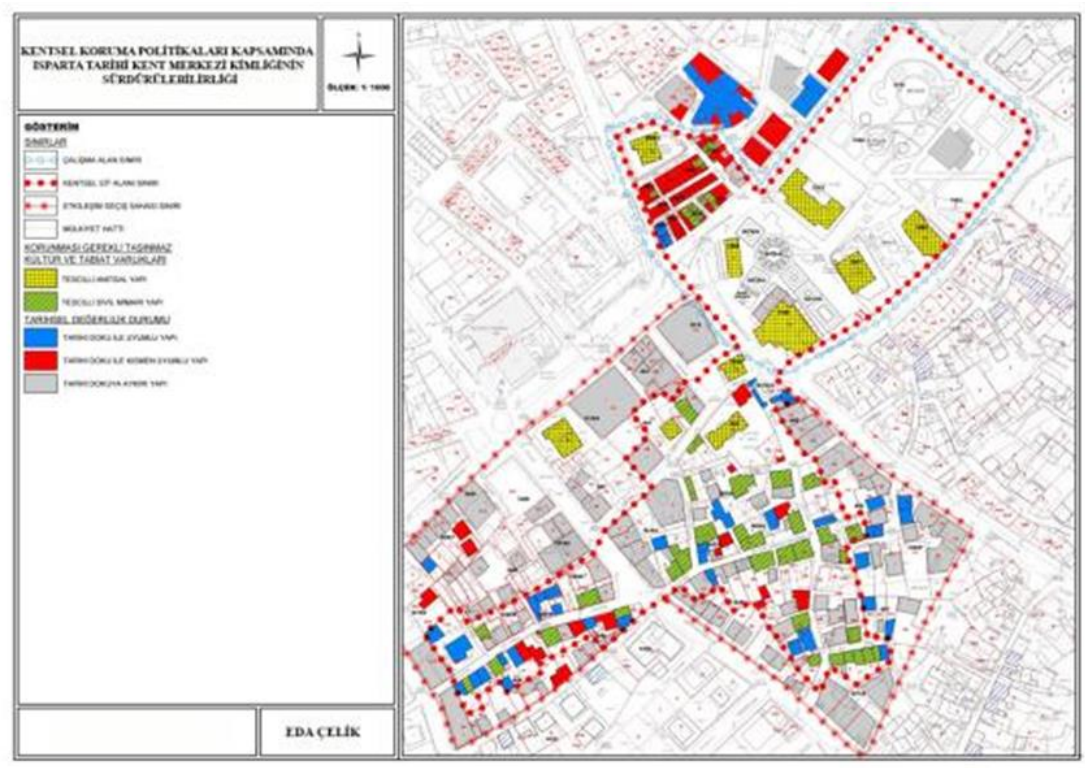

Şekil 3. Isparta Tarihi Kent Merkezi, simgesel yapılar

\section{Araştırma Sonuçları}

\section{1. Çalışma Alanı ve Yakın Çevresine Ait Analizler}

Çalışma alanı ve yakın çevresinin koruma sorunları ve kimlik değerleri bağlamında mevcut durumu, hâlihazır haritalar kullanılarak üretilen analitik haritalar yardımıyla analiz edilmiştir. Bu analizler, kat adedi analizi, yapı kullanım biçimi analizi, tarihsel dönemleme analizi, tarihi değerlilik analizi ve yapısal durum analizi olmak üzere 5 (beş) yönden ele alınmıştır.

\subsubsection{Kat Adedi Analizi}

Yapılan analiz çalışmalarına göre çalışma alanında bulunan 117 adet yapının yaklaşık \%20sini çok katlı yapılar oluşturmaktadır. Çok katlı yapıların tümü, tarihi kent merkezindeki yapılara göre görünüm-siluet ve cephe karaktersitiği bağlamında aykırı yapılardır. Bu yapılar çoğunlukla tarihi kent merkezinin hemen çevresindeki yeni ticari yapılardır. Yüksek katlı yeni yapılar haricinde alanda an fazla mevcut olan yapılar bodrum+2 katlı yapılardır (Tablo 1, Şekil 4).

Isparta'nın ilk imar planından kent kimliği bağlamında korunması öngörülen ve görünüm-siluet etkisini oluşturan yapı yükseklikleri, özellikle 1970 sonrasından itibaren süreç içinde müdahaleler ile bozulmuştur. $\mathrm{Bu}$ açıdan, tarihi kent merkezi ve yakınında bulunan "Korunacak Sokaklar", Koruma Kurulu kararı ile koruma statüsü altına alınması cephe karakteristiğinin korunması bakımından önemlidir. Ancak, tarihi kent merkezi yakın çevresinde özellikle son otuz yılda giderek artan yüksek yapılaşma eğilimlerinin kentin kimliğini olumsuz etkilediği görülmektedir.

Tablo 1. Kat Adedi Analizi

\begin{tabular}{c|c|c}
\hline \multicolumn{2}{c}{ KAT ADEDİ ANALiŻ } & ADET \\
\hline 1 KATLI YAPI & 6 & 5,13 \\
\hline BODRUM+1 KATLI YAPI & 6 & 5,13 \\
\hline 2 KATLI YAPI & 2 & 1,71 \\
\hline BODRUM+2 KATLI YAPI & 78 & 66,67 \\
\hline BODRUM+3 KATLI YAPI $V E$ ÜZERI KATLI YAPI & 24 & 20,51 \\
\hline TOPLAM & 1 & 0,85 \\
\hline
\end{tabular}




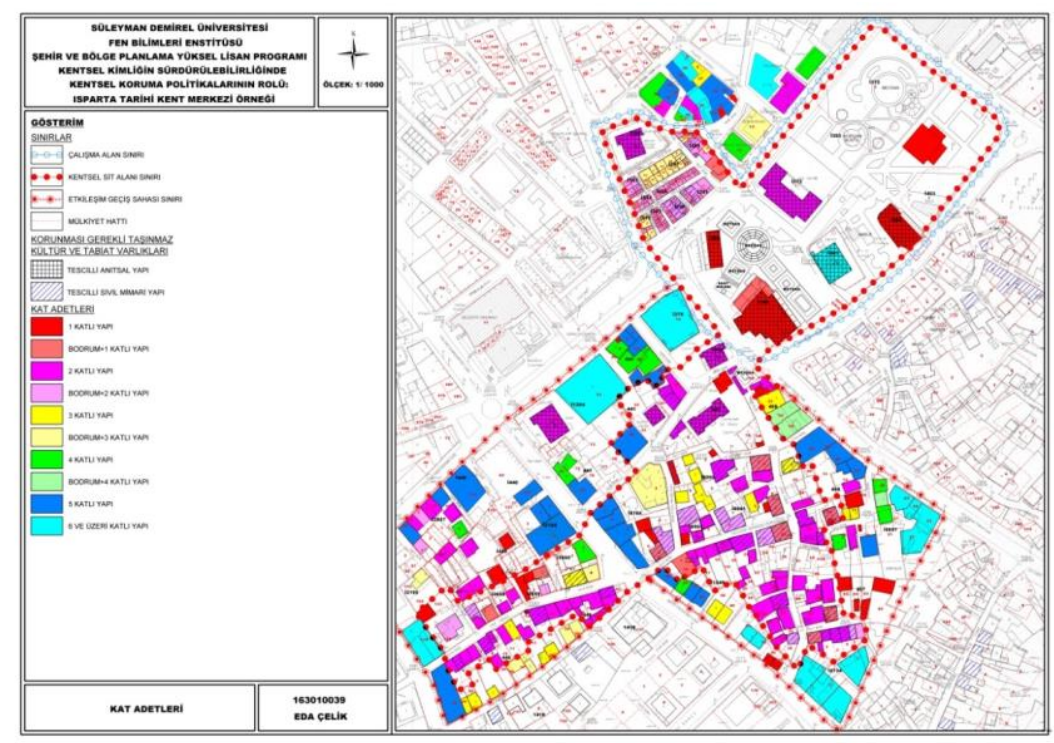

Şekil 4. Kat Adedi Analizi

\subsubsection{Yapı Kullanım Biçimleri Analizi}

Çalışma alanı Mimar Sinan Camii ve Üzüm Çarşısının bulunduğu kentsel sit alanı olarak ilan edilen ticari bölge ve bulunduğu kamusal ve tarihi niteliğe sahip anıtsal yapıların bulunduğu iki bölgeden oluşmaktadır. Alanda 2 adet dini tesis, 1 adet resmi kurum ve 114 adet ticaret yapısı vardır. Ticaret yapıları alandaki tüm yapıların yaklaşık $\% 98$ kısmını oluşturmaktadır (Tablo 2, Şekil 5).

Alanın çevresindeki yakın döneme tarihlenen ticari yapılar hem yüksek katlı oluşları nedeniyle, hem de ulaşım yapısındaki yükü artırmalarından dolayı kentin sahip olduğu kimliği olumsuz yönde etkilemişlerdir.

Tablo 2. Yapı Kullanım Biçimleri Analizi

\begin{tabular}{c|c|c}
\hline & YAPI KULLANIM BiÇIMLERI & $\mathbf{\%}$ \\
\hline DINI TESIS $($ CAMI) & ADET & 1,71 \\
\hline RESMI KURUM & 2 & 0,85 \\
\hline TICARET & 1 & 97,44 \\
\hline TOPLAM & 114 & $\mathbf{1 0 0 , 0 0}$ \\
\hline
\end{tabular}

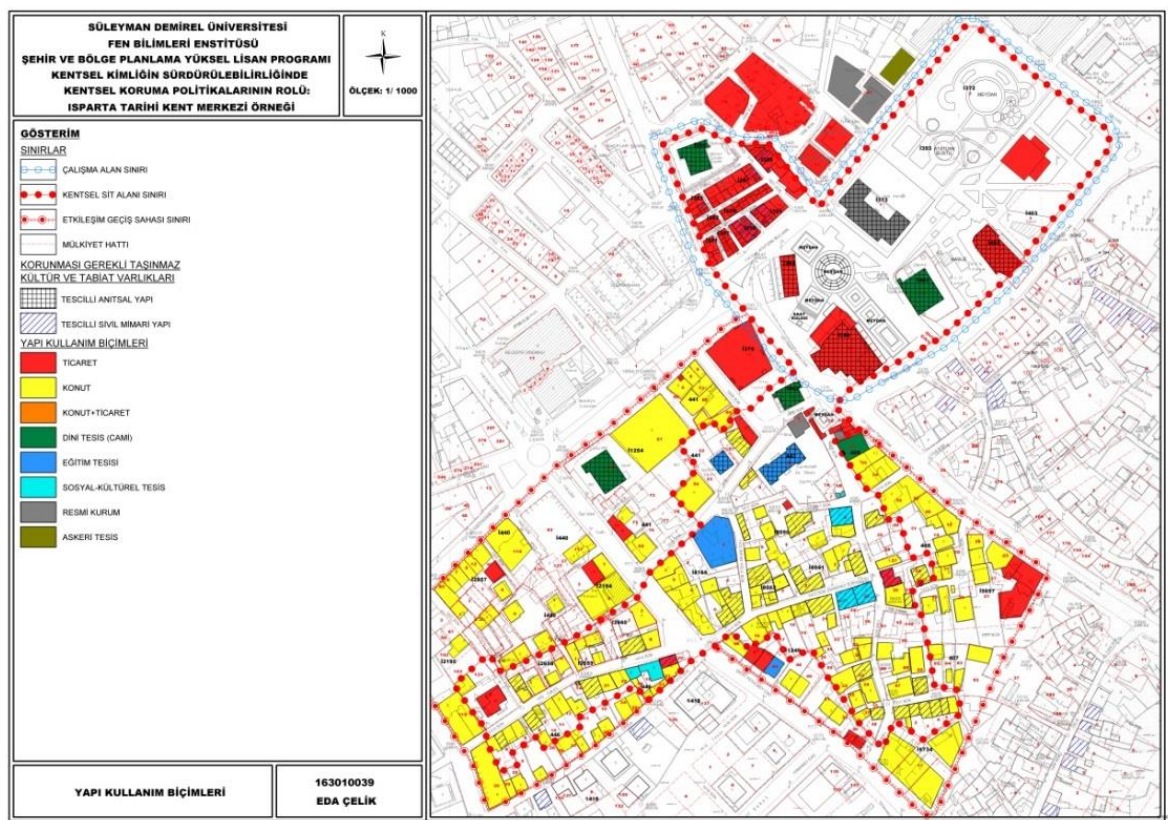

Şekil 5. Yapı Kullanım Biçimleri Analizi 


\subsubsection{Tarihsel Dönemleme Analizi}

Çalışma alanındaki anıtsal yapı niteliğindeki yapılardan en erken tarihli olan Mimar Sinan Camii ve camiye destek olması amacıyla yaptırılan Firdevs Bey Bedesteni ve Üzüm Çarşı'sı içerisindeki 16 adet dükkân ile Bey Hamam'1 16. Yüzyılda inşa edilmiş, Dalboyunoğlu Hamam'1 ise 17. Yüzyılda inşa edilmiş olan yapılardır. Valilik Binası ve alandaki diğer tüm yapılar 20. Yüzyılda inşa edilmiş olan yapılardır. Bu yapıların büyük bir kısmının çok katlı olmasının yanında, inşa edildikleri dönemin mimari üslubunu yansitan bodrum +1 ve bodrum +2 kat özelliğinde olan yapılar da vardır.
Çalışma alanının en yoğunluklu yapı grubunu \%80 ile 20 . Yüzyılda inşa edilen yapılar oluşturmaktadır (Tablo 3, Şekil $6)$.

20. yüzyılda inşa edilen yüksek katlı yapılar ile tarihi kent merkezindeki tarihsel doku bütünlüğünü yitirmiş, etrafında gelişen yeni çevre bu tarihi dokunun yok olmasına neden olmuştur. Kentin kimliğini oluşturan en önemli faktörlerden olan mimari kimlik bu yüksek katlı ve çevresiyle uyuşmayan yapılaşmalardan etkilenmiş, dolayısıyla kent kimliği bu durumdan zarar görmüştür.

Tablo 3. Tarihsel Dönemleme Analizi

TARIHSEL DÖNEMLEME

\begin{tabular}{|c|c|c|}
\hline & ADET & $\%$ \\
\hline 16.YÜZYIL & 19 & 16,24 \\
\hline 17.YÜZYIL & 1 & 0,85 \\
\hline 20.YÜZYIL & 94 & 80,34 \\
\hline 21.YÜZYIL & 3 & 2,56 \\
\hline TOPLAM & 117 & 100,00 \\
\hline
\end{tabular}

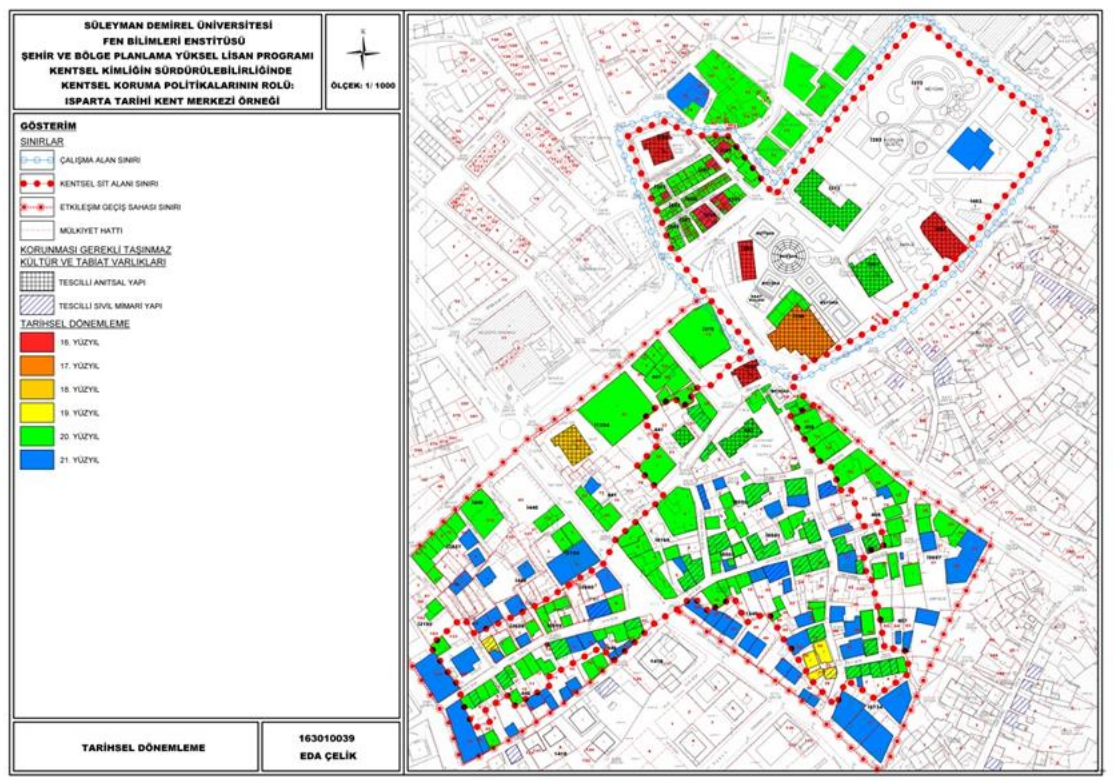

Şekil 6. Tarihsel Dönemleme Analizi

\subsubsection{Tarihi Değerlilik Analizi}

Isparta tarihi kent merkezindeki kentsel sit alanı ve mevcut yapıların Antalya Kültür ve Tabiat Varlıklarını Koruma Bölge Kurulu'nca tescillenmesi yapılmıştır. Alandaki en eski tarihli yapı olan Mimar Sinan Camii 10.02.2005 tarihli ve 241 sayılı karar ile tescil altına alınmıştır. Yine tarihi açıdan en eski yapılardan olan Firdevs Bey Bedesteni Gayrimenkul Eski Eserler ve Anitlar Yüksek Kurulu Başkanlığı'nın 13.05.1977 tarih ve A-548 sayılı kararı ile tesciline ve Antalya Kültür ve Tabiat Varlıklarını Koruma Bölge Kurulu'nun 25.09.1990 tarih ve 9021 sayılı kararıyla tescilinin devamına karar verilmiştir. Alanda bulunan Kutlubey (Ulu) Camii Gayri Menkul Eski Eserler ve Anitlar
Yüksek Kurulu Başkanlığı'nın 13.06.1977 tarih ve A-548 sayılı kararı ile tescillenmiş, Antalya Kültür ve Tabiat Varlıklarını Koruma Bölge Kurulu'nun 25.09.1990 tarih ve 901 sayılı kararı ile de tescilinin devamına karar verilmiştir. Alandaki Dalboyunoğlu Hamamı Antalya Kültür ve Tabiat Varlıklarını Koruma ve Bölge Kurulu'nun 1990 tarih ve 901 sayılı kararıyla, Valilik Bina'sı ise Antalya Kültür ve Tabiat Varlılarını Koruma ev Bölge Kurulu'nun 25.09.1990 tarih ve 901 sayılı karar ile tescillenmiştir.

Alanın ticari bölgesini oluşturan Üzüm Çarşısı ve Mimar Sinan Camii'nin bulunduğu alan Antalya Kültür ve Tabiat

Varlıklarını Koruma Kurulu'nun 26.07.1992 tarihli ve 1495 sayılı kararı ile kentsel sit alanı olarak ilan edilmiştir. 
Üzüm Çarşı'sı içerisindeki 16. yüzyıla tarihlenen 16 adet dükkân tescillenmiştir.

Tarihi kent merkezindeki resmi ve ticari yapılar olan Valilik Bina's1, Dalboyunoğlu Hamamı, Firdevsbey Bedesteni ve Ulu Cami'nin bir arada bulunduğu alan Antalya Kültür ve Tabiat Varlıklarını Koruma Kurulu'nca tarihi sit alanı olarak ilan edilmiştir.

Alandaki yapıların \%5 kısmı anıtsal yapılar, \%14 kısmı sivil mimarlık eserleri olmak üzere toplam \% 18 kısmı koruma altındaki tescilli yapılardan oluşmaktadır Diğer yapılar ise yapıldıkları dönem mimari üslupları çerçevesinde ve bir bütün olarak değerlendirildiğinde, \%6 kısmı tarihi doku ile uyumlu, \% $66 \mathrm{k} 1 \mathrm{sm} 1$ tarihi doku ile kısmen uyumlu \%9 kısmı ise tarihi dokuya aykırı yapılardan oluşmaktadır (Tablo 4, Şekil 7).

Alan bütününde tescilleme çalışmaları yapılmış olmasına rağmen tarihi doku büyük ölçüde kaybedilmiştir. Bu durum, alandaki kültür varlıklarının özgün niteliklerinin, uyumsuz ve aykırı yapılar nedeniyle tarihi çevrenin kimliksizleşme ya da kimliğini kaybetme riskini doğurmaktadır. Ancak, çalışma alanı ve yakın çevresinde özellikle son dönemde inşa edilmiş yeni yapıların -neredeyse- tümü tarihi çevrenin kimliğine aykırı yapılardır.

Tablo 4. Tarihsel Değerlilik Durumu Analizi

TARIHSEL DEĞERLİLIK DURUMU

\begin{tabular}{l|c|c}
\hline & ADET & $\mathbf{\%}$ \\
\hline TARIHI DOKU ILEE UYUMLU YAPI & 7 & 5,98 \\
\hline TARIHI DOKU ILE KISMEN UYUMLU YAPI & 77 & 65,81 \\
\hline TARIHI DOKUYA AYKIRI YAPI & 11 & 9,40 \\
\hline TESCILLI ANITSAL YAPI & 6 & 5,13 \\
\hline TESCILLI IIVIL MIMARI YAPI & 16 & 13,68 \\
\hline TOPLAM & $\mathbf{1 1 7}$ & $\mathbf{1 0 0 , 0 0}$ \\
\hline
\end{tabular}

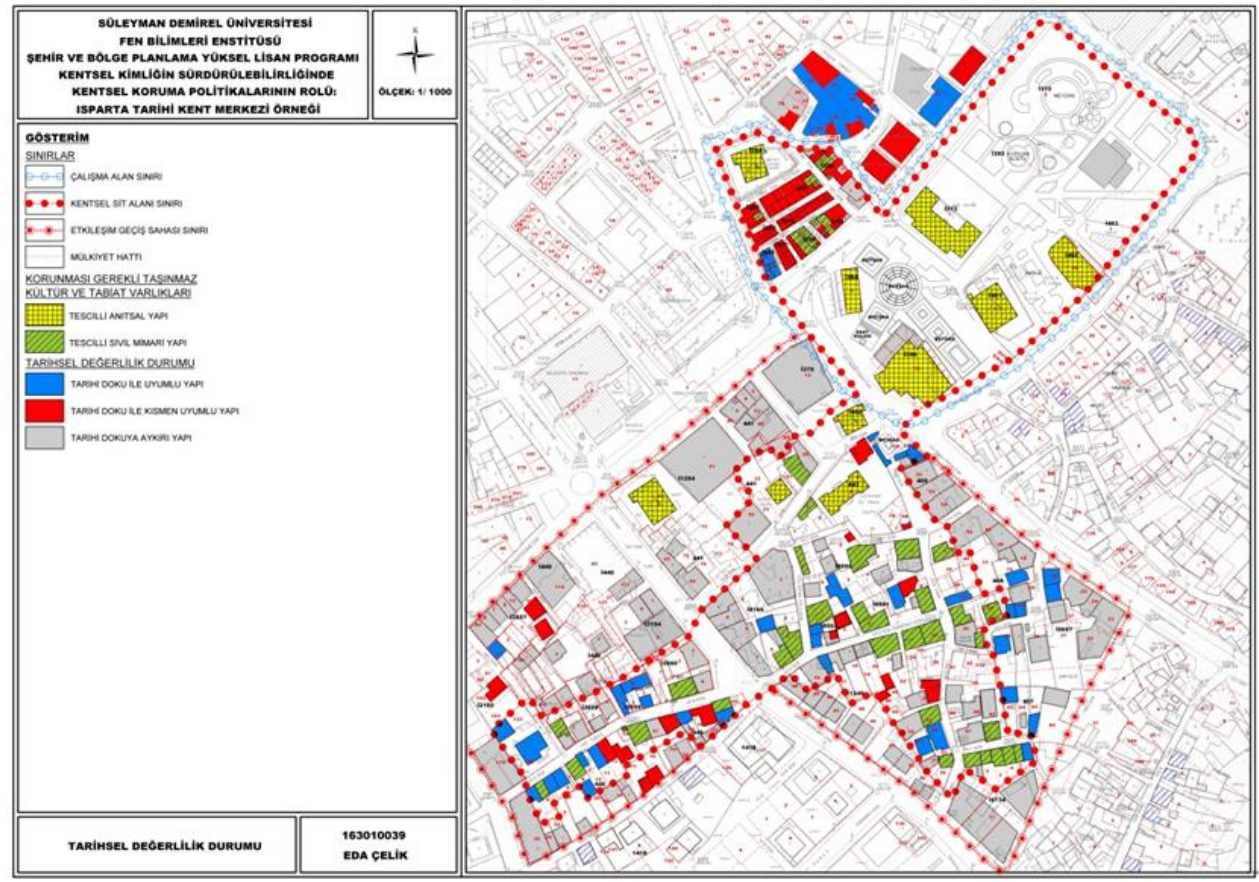

Şekil 7. Tarihsel Değerlilik Durumu Analizi

\subsubsection{Yaptsal Durum Analizi}

Bu analiz çalışmasında, çalışma alanında mevcut bulunan yapıların günümüzdeki yapısal durumları incelenmiştir. Sivil mimari özelliğinde olan yapıların tümü günümüze kadar yapısal durum özelliklerini sürdürmüş, aralarından bazıları belirli tarihlerde yapısal onarım görmüştür. Alanda bulunan yapıların yaklaşık \%81 kısmı orta derecede iyi, yaklaşık \%19 kısmı ise iyi durumdadır. İyi durumda olan yapıların tümü 19. yüzyıl ve 20. yüzyılda inşa edilen yapılardır. Alanda kötü durumda ya da harabe durumunda yap1 bulunmamaktadır (Tablo 5, Şekil 8).

Kentin Sivil mimari özellikli yapıları mimari üsluplarına uygun olarak onarım gördüklerinde, mevcudiyetlerini yüzyıllar boyunca koruyabilmekte, edinmiş oldukları mimari, tarihsel ve kültürel kimliklerini gelecek nesillere ulaştırabilmektedir. Yapılar günümüzde aktif olarak kullanılmakta, yapılan onarımlar sayesinde kullanım işlevlerini devam ettirmekte, bu durum da alanın canlılığını 
muhafaza etmesine yardımc olmaktadır. Bu durum kent

kimliğinin sürdürülmesinde önemli rol oynamaktadır.

Tablo 5. Yapisal Durum Analizi

\begin{tabular}{l|c|c}
\hline \multicolumn{3}{|c}{ YAPISAL DURUM } \\
\hline ADET & 22 & $\mathbf{\%}$ \\
\hline IYI DURUMDA YAPI & 95 & 18,80 \\
\hline ORTA DURUMDA YAPI & $\mathbf{1 1 7}$ & 81,20 \\
\hline TOPLAM & & $\mathbf{1 0 0 , 0 0}$ \\
\hline
\end{tabular}

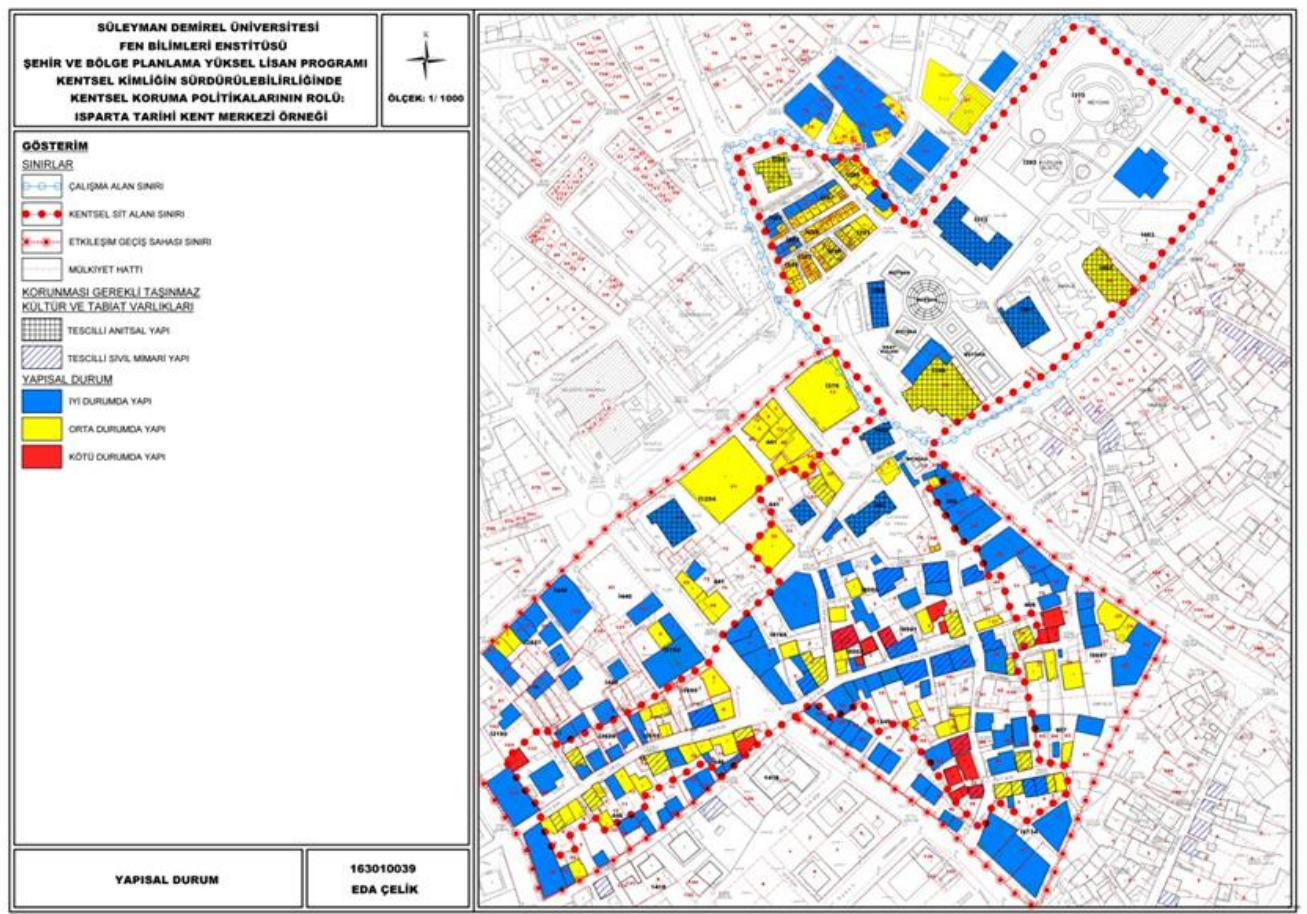

Şekil 8. Yapısal Durum Analizi

\section{Sonuç}

Çalışma alanı Isparta'nın tarihi niteliğe sahip kent merkezidir. Alanda ve yakın çevresinde mimari doku açısından büyük değişiklikler meydana gelmiş olmasına karşın, kendine has sokak yapısı ve barındırdığı tarihi yapılar ile kentin şu anki kullanıcılarına geçmişin izlerini yansitmaktadir.

Ticari ve kamusal kullanımlardan oluşan kentsel sit ve tarihi sit alanı kentin sosyal ve toplumsal yaşamını besleyen bir alan olması sebebiyle kent merkezi olma özelliğini devam ettirmektedir. Son yıllarda çeşitli ticari aktivitelerin yoğunlaşması nedeniyle tarihi yapı varlığı zarar görmekte, yok olma tehlikesiyle karşı karşıya kalmaktadır.

Kamusal işlev özelliği bulunan tarihi sit alanındaki yoğun araç trafiği alandaki tarihi değere sahip olan sivil mimari ve anıtsal yapıların önemli müdahalelere maruz kalmasına sebep olmuştur. Kent merkezinin günümüzde de merkez çevresine doğru gelişmesi nedeniyle alandaki yoğun taşıtlı trafik yolları artmış, yeni gelişen alanlarda dokuya uyum sağlamayan yapılar inşa edilmiştir.

Alandaki tarihi niteliğe sahip ticari bölge kentte artan alışveriş merkezleri nedeniyle eski cazibesini kaybetmiş, bu durumdan dolayı yapıların mülk sahipleri ekonomik açıdan e-ISSN: 2148-2683 yetersiz kaldıkları için yapıların bakımları yapılamamış, bu durum da tarihi dokunun kullanıcının zihninde oluşturduğu imajı olumsuz etkilemektedir.

Son yıllardaki imar çalışmaları ile alanın kentsel değerliliği canlandırılmaya çalışılmakta, bununla beraber alandaki betonarme ve çok katlı yapıların artması ile alan niteliksiz bir yapılaşma ile karşıya kalmakta, bu durum da geleneksel ve tarihi dokudaki bütünlüğe zarar vermektedir.

Çalışma alanında büyük ölçekli planlar ile alt ölçekteki uygulamaları arasında kopuk bir ilişkinin olduğu gözlemlenmiştir. Isparta kent merkezinde yer alan Isparta sit

alanına yönelik “Koruma Amaçlı İmar Planı” yapılmıştır. Yine aynı alana yönelik retorasyon çalışmaları yapılmış ve yapılmaya devam etmektedir. Fakat tek yapı ölçeğinde gerçekleştirilen koruma çalışmaları ile sit alanını kapsayan çalışmalar dışında kalan ölçekler için korumaya yönelik çalışamların eksikliği görülmektedir. Tek yapı ölçeğinde gerçekleştirilen uygulamaların kentsel bütüne dâhil edilememesi koruma anlayışının bütüncül yaklaşımına ters düşmektedir.

Alan ve yakın çevresinde bulunan tarihi dokuyla ve kent kimliğiyle uyuşmayan yapıların geneli kullanılır durumdadır. Taşıt trafiğinin az olduğu ulaşım akslarında tarihi değeri olan 
ve tescilli olan yapılar fazladır. Taşıt trafiğinin fazla olduğu ulaşım akslarında ise anıtsal niteliğe sahip yapılar yer almaktadır. Alanın büyük bir yoğunluğu trafiğe açı durumdadır. Çalışma alanı ve yakın çevresindeki ulaşımın yoğunluğu tarihi dokuyu olumsuz etkilemekte, çevresinde yer alan yeni yapılar ise tarihi dokuyla uyuşmazlık göstermektedir.

Kentin yapay çevre kimliğini oluşturan kent mobilyaları da kentin imajına ve kimliğine dair önemli unsurlardandır. Isparta kent bütününde ve tarihi kent merkezinde, Isparta'ya has karakteristik bir özellik olan gül unsurunun işlendiği kent mobilyaları yoğunluktadır. Fakat bu mobilyalar özellikle tarihi kent merkeziyle bütünlük oluşturmayan özellikte ve hacimdedir. Tarihi, kültürel ve ticari faaliyetlerin geçmişten günümüze kadar yoğun bir şekilde devam ettirildiği kent merkezinde bu yapılar fazladan yoğunluk oluşturmakta, aynı zamanda kentin tarihi ve kültürel kimliğine aykırılık oluşturmaktadır.

Tarihi niteliğe sahip olan yapılar inşa edildikleri tarihi dönemin toplumsal ve kültürel yapısına 1şık tutan birer kimlik elemanlarıdır. Zamanının toplumsal ilişkilerine, kültürel yapısına, geleneklerine, alışkanlıklarına ve hatta aile yapısına göre şekillenen bu tür yapılar ve bir arada bulunarak oluşturdukları kentsel doku günümüz müdahalelerine çoğu zaman uyum sağlayamamaktadır. Tarihi doku çevresinde gelişen ticaret alanları ve iş alanları bu dokunun eski canlılığını kaybetmesine, işlevsiz kalıp terk edilmesine neden olmaktadır. Tarihi kent merkezindeki yoğun ticaret ve hizmet sektörlerinin gelişimi, alandaki anıtsal yapıları ve oluşturdukları dokuyu zorlamakta, daha fazla fayda edinme amacının benimsenmesi sonucunda inşa edilen çok katlı binalar bu dokunun bozulmasına sebep olmakta, yapılan imar planı çalışmalarıyla gerçekleşen yoğunluk artışı bu dokuyu yok etmeye sürüklemektedir.

Çalışma alanının yer aldığı tarihi kent merkezi ve oluşturduğu dokuyu korumak amaçlanmış ve planda kentin gelişme yönünün tarihi kent merkezinin tersi yönde olması hedeflenmiştir. Hükümet meydanı olarak karar verilen alana inşa edilen Valilik Bina'sı tarihi kent merkezine ters konumlandırıldığı için gelişim, İstasyon Caddesi yönünde olmuş fakat bu durum tarihi kent merkezinin arka planda kalmasına sebebiyet vermiştir. Günümüzdeki imar planı çalışmalarında da tarihi kent merkezinin korunmasına yönelik kararlar geliştirilmemekte, alanın cazibesinin yeniden kazandırılması için işlevsel yoğunluk artırılmaktadır. Bu durum ise tarihi kent merkezi ve çevresinde yoğun bir yapılaşmanın meydana gelmesine neden olmaktadır. Dolayısıyla bu yoğun yapılaşma ve işlevsel yük alanın sahip olduğu kimliğin tehlikeye düşmesine neden olmaktadır.

Kentsel gelişim ile birlikte kentin merkezinde bulunan tarihi kent merkezleri, sahip odlukları kendine has özellikler ve kimlikleri açısından zarar görmektedirler. $\mathrm{Bu}$ durumun sebebi kentin kimliğinin meydana gelmesinde tüm tarihi sürecin, bu süreçte kentte ikamet edenlerin sosyal yapısının ve geçmiş ile gelecek arasında bağ kurmayı hedefleyen yasal düzenlemelerin öneminin farkında olunmamasıdır. Bu yüzden koruma çalışmalarında üst ölçek itibari ile bütünsel hareket edilmemekte, yerinde ve noktasal müdahaleler ile alandaki sorunlar ortadan kaldırılmaya çalışılmaktadır. Tüm bu faaliyetlerin bir kentin kimliğinin sürdürülebilir olmasındaki etkisi büyüktür. Bunlardan etkilenen bir tarihi mekânsal alan da Isparta tarihi kent merkezidir.

Çalışma alanında yer alan yapılar işlevleri bakımından kamusal, ticari ve konut olarak üç farklı işlevdedir. Bu alanı tanımlayan sit sınırının yeterli genişlikte olmaması sebebiyle kent merkezinin dokusunu bozacak niteik ve yükseklikte binalar inşa edilmektedir. Sit alanı içerisinde yer alan boş parseller yakın çevredeki parseller ile birleştirilip kent merkezinin otopark ihtiyacı bu şekilde çözülmeye çalışılmaktadır. Sit sınırının yeterli genişlikte olması ile dokudaki bozulmaların önüne geçilebileceği düşünülmektedir.

Çalışma alanı içerisinde ve yakın çevresinde yer yapıların mevcut işlevlerinin devam ettirilmesi, başka işlevlerin bu alanda yoğunlaşmasına izin verilmemesi alanın ve yakın çevresinin kullanım yoğunluğunu dengede tutmaya yarayacaktır.

Tarihi dokularını koruyan yerleşmelerde ulaşımın motorlu taşıtlarla yapılması ve tarihi kent merkezindeki taşıt trafiğinin yoğun olması bu dokuya zarar verebilmektedir. Bu sebeple alan ve yakın çevresinde yayalaştırma çalışmaları yapilmalidir.

Sonuç olarak kentsel kimliğin sürdürülebilirliğinde kentin çekirdeğini oluşturması nedeniyle tarihi kentsel alanlarda ve kent bütünündeki fiziksel, ekonomik, sosyal ve kültürel yapının kapsayıcı politika ve stratejiler ile korunması gerekmektedir.

Tarihi kent merkezleri ve yakın çevreleriyle oluşturduğu dokuda, koruma ve sürdürülebilirlik çalışmaları tek yap1 ölçeğinden tüm alan ölçeğine kadar genişletilmeli, alandaki doku sosyal, fiziksel ve kültürel yapısıyla bir bütün olarak düşünülmeli ve kentin kimliğinin sürdürülebilir olması için bu unsurların korunması gerekmektedir. Kent kimliğinin gelecek nesillere aktarılmasını ve sürdürülebilir olmasını sağlayacak en önemli aracın kentsel koruma politikaları olduğunu unutmamak gerekmektedir.

Korunması gereken alanlara yönelik koruma yaklaşımları kentsel ölçekte, daha evvelden mevcut olan ve koruma sürecinin her safhasında mutlaka göz önünde bulundurulması gereken yapı varlığının, kentin tamamında yaşanan değişim ve gelişmelere devamlı olarak uyarlanması şeklinde olmalıdır. $\mathrm{Bu}$ sebeple tüm alanlardaki planlama sürecinin sahip olduğu yapısal değerler, hem plan açısından hem de kendi varlığını sürdürme açısından gelecekte oluşması muhtemel yeni koşullar göz önünde bulundurularak önemsenmelidir.

Yapılardaki fiziksel yıpranmaların önüne geçmek maksadıyla bakım ve onarımlarında süreklilik sağlanmalıdır. Kentsel koruma alanları ile çevredeki alanlara yönelik alınan kararların bir bütün olması sağlanmalıdır.

Kentsel dokuya zarar verecek nitelik ve görünüşteki yapılar, koruma alanlarında alınacak planlama kararları ile yok edilmelidir. Toplumun geçmişte içerisinde bulunduğu sosyal ve ekonomik şartları ve kültürel değerlerini yansıtan fiziksel yapısının günümüzün değişen sosyo-ekonomik şartlarında yok olmasına engel olmak, çağdaş gelişmelerle bütünleşerek kentsel kimliğin devam etmesini sağlamak gerekmektedir.

Isparta tarihi kent merkezi kimliğinin sürdürülebilirliği açısından kentsel koruma politikaları önem taşımaktadır. Koruma tek yap1 ölçeğinde olabilmesinin yanı sıra yapı gruplarının oluşturduğu kentsel dokuyu kapsayan ölçekte de 684 
olabilmektedir. Tarihi kent merkezi için koruma politikaları geliştirilirken alan için uygulanacak planda yapılar ve tarihi kent dokusu kent bütününden ayrı düşünülmemeli, kentin bütünüyle uyum sağlaması amaçlanmalıdır.

Tarihi sit alanı ve kentsel sit alanı içerisinde bulunan yapıların tescil çalışmaları yapılmalı, zamanla tahrip olmalarına yönelik yenileme ve düzenleme çalışmaları yapılmalı, alanda gerçekleşecek yeni yapılanmaların denetimi iyi yapılmalidir.

Alandaki köhneleşmenin önüne geçilmeli, mevcut yapılar bakımsız birakılmamalı, mevcut potansiyelleri değerlendirilmeli ve dengeli bir şekilde alanın eski cazibesini kazanması sağlanmalıdır. Tarihi dokunun varlığını devam ettirmesi ve gelecek nesillere aktarılabilmesi için alan işlevsel olarak canlandırılmalıdır.

Alanda sit dokusuna daha fazla zarar verecek işlevsel, fiziksel ve sosyo-ekonomik açıdan farklılık teşkil eden yapılaşmalar önlenmeli, alanın klasik Osmanlı şehri yapılanması muhafaza edilmelidir.

Bu sebeple alanı kapsayan koruma çalışmalarının artması, mekândaki değişiklikler doğrultusunda güncellenmesi, alana dair geliştirilen politikaların uygulanması ve takibinin sağlanması alandaki kimliğin sürdürülüp gelecek nesillere aktarılmasında önem taşımaktadır.

\section{Kaynakça}

Anonim. 2009. Isparta İl Kültür Envanteri Isparta: T.C. Isparta Valiliği İl Kültür Turizm Müdürlüğü Yayınları.

Clammer, J. (2003). Globalization, class, consumption and civil society in South east Asian cities. Urban Studies, 40, 403-419. Retrieved March 19, 2007, from EBSCOhost Academic Search Premier database.

Erkmen, B. (1990). Şehir Kimliği Ve Şehir Mobilyası Üzerine. Arredamento Dekorasyon, Boyut Yayın Grubu, İstanbul, 17: 126-7.

Gündüz, O. Ve Taner, T. (2001). Küreselleşme Sürecinde Türk Kentlerinin Kimlik Sorunları Ve İzmir Örneği. 1.Uluslar Arası Kentsel Tasarım Buluşması, Mimar Sinan Güzel Sanatlar Üniversitesi, İstanbul.

Isparta Belediyesi. (2014). Kentsel Sit Alanı Ve Etkileme Geçiş Bölgesi Koruma Amaçlı İmar Planı. Isparta: Isparta Belediyesi.

Isparta Belediyesi. (2019). Isparta İlk İmar Planı. Isparta

İlgar, E. (2008). Kent Kimliği Ve Kentsel Değişimin Kent Kimliği Boyutu Eskişehir Örneği. Yüksek Lisans Tezi, Anadolu Üniversitesi Fen Bilimleri Enstitüsü, Mimarlık Anabilim Dalı, Eskişehir.

Jacobs, Jane. Büyük Amerikan Şehirlerinin Ölümü ve Yaşamı. İstanbul : Metis Yayınları, 2011

Kong, L. L. (2000). Value Conflicts, Identity Construction, and Urban Change. In LeGates, R. \& Stout, F. (Eds.), (pp. 354-365). The City Reader, London.

Kroft, K. (1996). Urban tissue and the character of towns. Urban Design International, 1(3), 247-263.

Lynch, Kevin. Kent İmgesi. İstanbul : Türkiye İş Bankası Kültür Yayınları, 2017.

Oktay, D., 2007. Sürdürülebilirlik Yaşanılabilirlik Ve Kentsel Yaşam Kalitesi: Kavramdan Uygulamaya. Mimarlık Dergisi, 335, 37-40.

Öelsner, P. R. (1942). Isparta'ya 1942 Ağustosundaki Seyahatin Raporu. Ün Dergisi, 1812-1814.

e-ISSN: 2148-2683
Paul, D. (2004). World cities as hegemonic projects: the politics of global imagineering in Montreal. Political Geography, 23, 571- 596.

Şahin, M.N. (2010). Kent Kimliği Ve Değişim Sürecinin Kayseri Kenti Örneğinde İrdelenmesi. Yüksek Lisans Tezi, Mimar Sinan Güzel Sanatlar Üniversitesi Fen Bilimleri Enstitüsü, Şehir Ve Bölge Planlama Anabilim Dalı, İstanbul.

Tekeli, İ., 1991. "Bir Kentin Kimliği Üzerine Düşünceler", Kent Planlaması Konuşmaları, TMMOB Mimarlar Odası Yayınları, s. 79-89, Ankara.

Türk, A., Polat, E., \& Kıstır, M. R. (2013). Isparta İdare Mahkemesi Başkanlığı'na Bilirkişi Raporu. 